\title{
CHARACTERISTICS OF THE CHURCH IN GORICA NEAR LIVNO
}

\author{
GLIBIC, M. \& COLAK, I.
}

Abstract: In the world, application of reinforced concrete for construction of civil engineering structures began in last decades of the 19th century. In our areas, it is only in the beginning of the 20th century that construction of structures of reinforced concrete started, and the first reinforced-concrete structure was the small bridge in Ogulin in Lika, built in 1900 (***, 2005). Knowing of that fact, the discovery of the original project (Figure 1) for vault superstructure of the church in Gorica near Livno from 1903 was a big surprise, but also pleasure (Vancaš, 1903). Together with the project was the complete bill of costs for the works (Figure 2), which, in addition to its historical, heritage and construction significance, probably has a linguistic value too. In fact, it was a true pleasure to turn pages of over a hundred years old papers and to enjoy the found material. Namely, the project anticipated application of reinforced concrete in the construction of the new church vault. Two years later, the new vault was constructed according to this project. The author of the project was the well-known architect Josip Vancaš from Sarajevo.

Key words: construction of church, reinforced concrete, Josip Vancaš, damages on the church
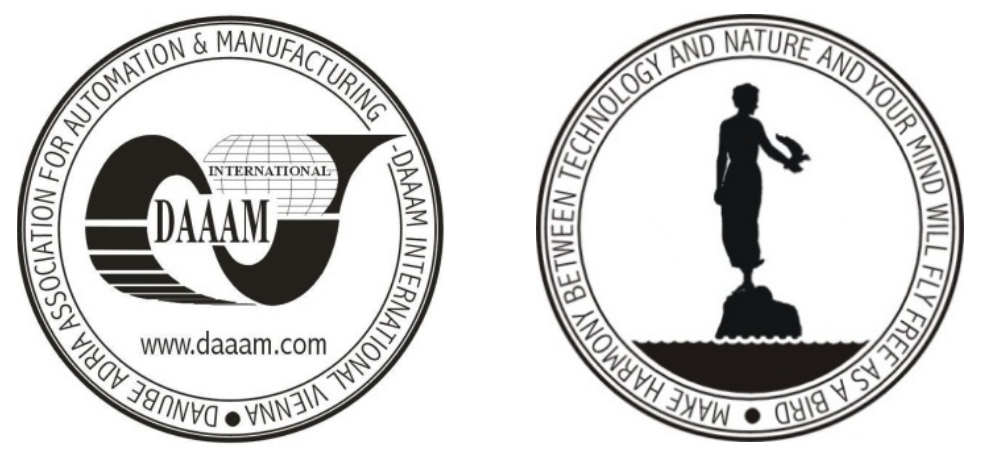

Authors data: Ph.D. Glibic, M[laden]; Ph.D. Colak, I[vo], University of Mostar, Faculty of Civil Engineering, Matice hrvatske bb, mladen.glibic@gfmo.ba, BH88000 Mostar, Bosnia and Herzegovina

This Publication has to be referred as: Glibic, M[laden] \& Colak, I[vo] (2009). Characteristics of the Church in Gorica Near Livno, Chapter 72 in DAAAM International Scientific Book 2009, pp. 751-762, B. Katalinic (Ed.), Published by DAAAM International, ISBN 978-3-901509-69-8, ISSN 1726-9687, Vienna, Austria DOI: $10.2507 /$ daaam.scibook.2009.72 